\title{
PEMANFAATAN PUPUK ORGANIK DAN INOKULAN BAKTERI PELARUT FOSFAT UNTUK MENINGKATKAN SERAPAN P, PERTUMBUHAN DAN HASIL TANAMAN KEDELAI (Glycine max L.)
}

\section{Apllication of Organic Manure and Phosphate Solubilizers Bacteria for Increasing the P-Uptake, Growth and yield of Soybean (Glycine max L.)}

\author{
Fajar Setyawan* dan Muhammad Hadi Santoso \\ Agroteknologi Fakultas Pertanian Universitas Islam Kadiri \\ Jl. Sersan Suharmaji No.38, Manisrenggo, Kec. Kota Kediri, Kota Kediri, Jawa Timur 64128
}

Alamat korespodensi: fajar setyawan26@yahoo.com

\begin{abstract}
ABSTRAK
Pupuk organik dan ketersediaan hara berperan penting dalam menunjang pertumbuhan dan perkembangan tanaman. Kandungan pupuk organik dan ketersediaan $\mathrm{P}$ yang rendah merupakan faktor pembatas utama untuk budidaya tanaman kedelai pada tanah masam. Penelitian untuk mengkaji aplikasi pupuk organikdan bakteri pelarut fosfat (BPF) untuk meningkatan serapan P, pertumbuhan dan hasil tanaman kedelai. Dilakukan dari September - Desember 2019 di Laboratorium Lapang Terpadu Universitas Islam Kadiri. Percobaan menggunakan rancangan acak kelompok (RAK) faktorial dan diulangan 3 kali. Faktor pertama adalah pupuk organik yang terdiri dari (Pupuk kandang ayam, Pupuk kandang sapi dan Pupuk hijau paitan, masing-masing dengan dosis 10 ton/ha) dan Perlakuan Kedua adalah inokulan BFF yang terdiri dari 4 konsentrasi (0, 3, 6, 9 $\mathrm{ml} / \mathrm{l}$ ).Parameter yang diamati: laju tumbuh, jumlah polong per tanaman, indeks panen (IP) dan bobot kering biji. Interaksi antara pemberian pupuk organik dengan inokulasi BPF mempengaruhi laju tumbuh, serapan P dan hasil tanaman kedelai. Aplikasi 10 t/ha pupuk kandang sapi dan BPF dengan konsentrasi $6 \mathrm{ml} / 1$ mampu meningkatkan laju tumbuh sebesar 2,6\% dan serapan P 0,08\% dibandingkan dengan tanpa inokulasi BPF. Aplikasi 10 t/ha pupuk kandang sapi dan BPF dengan konsentrasi $6 \mathrm{ml} / \mathrm{l}$ mampu menghasilkan 2,7 t/ha biji kedelai.
\end{abstract}

Kata kunci: bakteri pelarut fosfat, pupuk organik, tanaman kedelai

\begin{abstract}
Organic fertilizers and nutrient availability play an important role in supporting plant growth and development. Low organic matter content and P-availability are the main limiting factors for soybean cultivation on acid soils. Research to examine the application of organic fertilizers and phosphate solubilizing bacteria $(B P F)$ to increase $P$ uptake, growth and yield of soybean plants. Conducted from September December 2019 at the Integrated Field Laboratory of the Islamic University of Kadiri. The experiment used a factorial randomized block design (RBD) and was given 3 replications. The first factor is organic fertilizer consisting of (chicken manure, cow manure and paitan green fertilizer, each with a dose of 10 t/ha) and the second treatment is BFF inoculant consisting of 4 concentrations $(0,3,6,9 \mathrm{ml} / \mathrm{l})$. Observed parameters: growth rate, number of pods per plant, harvest index and dry weight of seeds. The interaction between organic fertilizer application with BPF inoculation influences growth rate, $P$ uptake and soybean yield. Application of 10 t/ha cow manure and BPF with a concentration of $6 \mathrm{ml} / \mathrm{l}$ was able to increase the growth rate by $2.6 \%$ and $P$ uptake $0.08 \%$ compared to without BPF inoculation. Application of $10 \mathrm{t} / \mathrm{ha}$ cow manure and BPF with a concentration of $6 \mathrm{ml} / \mathrm{l}$ was able to produce 2.7 thaof seeds.
\end{abstract}

Keywords: phosphate solubilizers bacteria, organic fertilizer, soybean

\section{PENDAHULUAN}

Kedelai salah satu komoditas pangan utama di Indonesia yang memiliki banyak produk olahan yang menjadi kebutuhan sehari-hari masyarakat seperti tempe, tahu dan kecap.Salah satu permasalahan yang mempengaruhi produktifitas tanaman kedelai di Indonesia yaitu, lahan kritis yang semakin bertambah luas yang disebabkan oleh erosi atau menurunnya 
tingkat kesuburan tanah karena banyaknya petani yang menggunakan pupuk kimiawi secara terus menerus. Pengelolaan lahan yang ada saat ini hanya semata- mata bertumpu pada perbaikan pertumbuhan tanaman dan peningkatan hasil produksi tanaman tanpa mempertimbangkan dampak yang terjadi dalam jangka panjang.

Pemanfaatan pupuk organik yang tepat pada media tanam dapat meningkatkan kualitas pertumbuhan dan produktivitas tanaman. Pupuk organik akan mengalami proses dekomposisi dan mineralisasi untuk melepaskan nutrisi, baik unsur hara makro maupun mikro. Disamping itu pupuk organik juga mampu memperbaiki sifat fisik tanah seperti permeabilitas tanah, porositas tanah, strukur tanah, daya serap atau daya pegang terhadap air, dan kation-kation tanah (Safrianto et al., 2015). Jenis pupuk organik sangat beragam berdasarkan asal bahan pembentuknya, seperti pupuk yang berasal dari kotoran hewan atau pupuk yang menyediakan mikroba hidup sebagai inokulan. Dulur (2010), bahwa penambahan bahan organik ketanah akan mengalami dekomposisi sehingga melepaskan berbagai senyawa organik yang mengandung fosfat seperti fosfolipit, gula-gula fosfat, asam nucleat, nukleoprotein sehingga pada akhirnya akan meningkatkan P-organik tanah.
Berdasarkan Penelitian Setyawan danSetyawan (2019) aplikasi pupuk SP36 $200 \mathrm{~kg} / \mathrm{ha}$ dengan pupuk organik asam humat $50 \mathrm{~kg} / \mathrm{ha}$ dapat meningkatkan produksi tanaman kedelai sebesar $43 \%$ dibandingkan dengan tanpa SP36 dan tanpa asam humat. Rismawan et al. (2018) Perlakuan pupuk kandang kambing 20 t/ha mampu meningkatkan jumlah polong isi, bobot biji dan hasil per hektar tanaman kedelai.

Mikroorganisme tanah yang mampu menyediakan unsur hara bagi tanaman adalah bakteri pelarut fosfat. Bakteri pelarut fosfat adalah kelompok mikroba yang dapat mengubah fosfat tidak terlarut dalam tanah menjadi bentuk yang larut dengan mensekresikan asam-asam organik dan melarutkan $\mathrm{P}$ yang teradsorpsi oleh senyawa (Widawati dan Suliasih, 2006). Inokulasi bakteri pelarut fosfat ke dalam tanah juga akan semakin mempercepat proses dekomposisi bahan organik, sehingga akan mempercepat penambahan P-organik. Berdasarkan penelitian Setyawan (2017) pemberian bakteri pelarut posfat B.subtilis dengan $6 \mathrm{ml} / \mathrm{l}$ dengan pupuk kandang sapi 18,5 t/ha meningkatkan populasi B. subtilis sebesar $86,1 \%$ dan Indek panen $66,6 \%$. Tujuan penelitian ini mengetahui interaksi antara pupuk organik dan bakteri pelarut fospat terhadap serapan $\mathrm{P}$, pertumbuhan tanaman dan hasil tanaman kedelai. 


\section{METODE PENELITIAN}

Penelitian bulan September Desember 2019 bertempat di Laboratorium Lapang Terpadu Universitas Islam Kadiri. Karakteristik tekstur tanah lempung berpasir dengan $\mathrm{pH}$ tanah 5,02, C- organik 2,51\% dengan ketinggian tempat $67 \mathrm{mdpl}$. Alat yang digunakan dalam penelitian ini antara lain: soil tester, timbangan, kamera. Bahan yang digunakan terdiri dari benih kedelai varietas Grobogan, bakteri pelarut fosfat (BPF) B.subtilis kepadatan $10^{8} \mathrm{cfu} / \mathrm{ml}$ diperoleh dari Laboratorium HPT Universitas Brawijaya, pupuk hijau paitan (kandungan kimia: C- Organik: $35,45 \%, \mathrm{~N}: 2,51 \%$, P: $0,48 \%$, dan $\mathrm{K}$ : 0,99\%), pupuk kandang sapi (kandungan kimia: C- Organik: 18,79\%, N: 0,80\%, P: $0,24 \%$, dan $\mathrm{K}: 1,36 \%$ ) dan pupuk kandang ayam(kandungan kimia: C- Organik: 24,8 $\%$, N: 2,15\%, P: 1,23\%, dan K: 1,33\%).

Penelitian dilaksanakan secara faktorial dengan menggunakan Rancangan Acak Kelompok (RAK) terdiri dari dua faktor, diulang sebanyak 3 kali. Faktor I: Pupuk organikorganik $(\mathrm{P})$ yang terdiri dari 3 level: $\mathrm{P}_{1}=$ Pupuk kandang ayam 10 ton/ha, $\mathrm{P}_{2}=$ Pupuk kandang sapi 10 ton/ha, $\mathrm{P}_{3}=$ Pupuk hijau paitan 10 ton/ha. Faktor II: Bakteri pelarut fosfat (B) yang terdiri dari 4 level: $\mathrm{B}_{0}$ : Tanpa Bakteri pelarut fosfat, $\mathrm{B}_{1}$ : ( $\left.3 \mathrm{ml} / \mathrm{l}\right), \mathrm{B}_{2}$ : ( $\left.6 \mathrm{ml} / \mathrm{l}\right), \mathrm{B}_{3}:(9$ $\mathrm{ml} / \mathrm{l}$ ). Petak penelitian dengan ukuran masing- masing $2 \mathrm{~m}$ x 2,5 m sebanyak 36 petak. Aplikasi pupuk organik sesuai perlakuan sebagai pupuk dasar dengan aplikasi 2 minggu sebelum tanam (hst), sedangkanaplikasi BPF pada tanaman berumur 7 hst, 21 hst dan 35 hst sesuai perlakuan. Penanaman dengan jarak tanam yang digunakan $25 \mathrm{~cm}$ x $25 \mathrm{~cm}$. Parameter yang diamati laju tumbuh tanaman, serapan unsur hara $\mathrm{P}$, jumlah polong per tanaman, indeks panen dan bobot kering biji (t/ha). Data yang diperoleh dianalisis dengan menggunakan analisis ragam (uji F) pada taraf 5\% untuk mengetahui pengaruh perlakuan. Hasil analisis ragam yang nyata dilanjutkan dengan uji Beda Nyata Terkecil pada taraf nyata 5\% untuk mengetahui perbedaan diantara perlakuan.

\section{HASIL DAN PEMBAHASAN}

\section{Laju Tumbuh}

Interaksi pemberian pupuk organik dan bakteri pelarut pospat (BPF) mampu meningkatkan laju tumbuh 42-56 hst. Laju tumbuh akibat interaksi, dapat disajikan pada (Tabel 1).

Pengamatan laju tumbuh tanaman 42-56 hst diketahui bahwa pemberian pupuk kandang sapi 10 t/ha dengan bakteri pelarut pospat $6 \mathrm{ml} / \mathrm{l}$ dan $3 \mathrm{ml} / 1$ memberikan pengaruh yang nyata dibandingkan dengan $0 \mathrm{ml} / \mathrm{ldan} 9 \mathrm{ml} / \mathrm{l}$. Pupuk Kandang Ayam 10 t/ha dengan 
bakteri pelarut pospat $6 \mathrm{ml} / \mathrm{l}$ memberikan $\quad \mathrm{ml} / \mathrm{ldan} \quad 9 \quad \mathrm{ml} / \mathrm{l}$.Pupuk kandang pengaruh nyata dibandingkan dengan0

Tabel 1. Interaksi pemberian pupuk organik dan bakteri pelarut phosfat terhadap laju tumbuh tanaman kedelai umur $42-56 \mathrm{hst}\left(\mathrm{g} / \mathrm{m}^{2} / \mathrm{hari}\right)$

\begin{tabular}{|c|c|c|c|}
\hline \multirow{2}{*}{$\begin{array}{c}\text { Perlakuan } \\
\text { Bakteri Pelarut Pospat }\end{array}$} & \multicolumn{3}{|c|}{ Pupuk organik } \\
\hline & $\begin{array}{c}\text { Kandang Ayam } \\
10 \mathrm{t} / \mathrm{ha}\end{array}$ & $\begin{array}{c}\text { Kandang Sapi } \\
10 \mathrm{t} / \mathrm{ha}\end{array}$ & $\begin{array}{l}\text { Paitan } \\
10 \text { t/ha }\end{array}$ \\
\hline 0ml/liter air & $1,61 \quad \mathrm{a}$ & 1,49 a & $3,13 \quad b$ \\
\hline $3 \mathrm{ml} /$ liter air & $1,99 \quad a b$ & $4,88 \mathrm{c}$ & 1,48 a \\
\hline $6 \mathrm{ml} /$ liter air & $4,77 \quad c$ & $5,48 \quad \mathrm{c}$ & $1,31 \quad \mathrm{a}$ \\
\hline $9 \mathrm{ml} /$ liter air & $1,30 \quad \mathrm{a}$ & $1,65 \mathrm{ab}$ & $2,76 \quad b$ \\
\hline BNT 5\% & & 1,30 & \\
\hline $\mathrm{KK} \%$ & & 29,20 & \\
\hline
\end{tabular}

Keterangan: bilangan yang didampingi huruf yang sama tidak berbeda nyata berdasarkan pada BNT $5 \%$.

ayam 10 t/ha dengan bakteri pelarut pospat

$6 \mathrm{ml} / \mathrm{l}$ memberikan pengaruh yang nyata dibandingkan dengan $0 \mathrm{ml} / \mathrm{l}, 3 \mathrm{ml} / \mathrm{ldan} 9$ ml/l. Sedangkan pupuk hijau paitan $10 \mathrm{t} / \mathrm{ha}$ dengan bakteri pelarut pospat $0 \mathrm{ml} / \mathrm{l}$ dan 9 $\mathrm{ml} / \mathrm{l}$ memberikan pengaruh yang nyata dibandingkan dengan $3 \mathrm{ml} / \mathrm{ldan} 6 \mathrm{ml} / \mathrm{l}$, tetapi pemberian pupuk hijau paitan $10 \mathrm{t} / \mathrm{ha}$ dengan bakteri pelarut pospat $0 \mathrm{ml} / \mathrm{l}$ tidak memberikan pengaruh nyata dibandingkan dengan $9 \mathrm{ml} / \mathrm{l}$. Hal ini disebabkan pupuk kandang sapi dengan dikombinasikan bakteri pelarut pospat $6 \mathrm{ml} / \mathrm{lmampu}$ terdekomposisi dengan baik sehingga penyediaan hara untuk tanaman kedelai semakin cepat. Pupuk kandang sapi memiliki kandungan : C- Organik: 18,79\%, $\mathrm{N}: 0,80 \%$, P: 0,24\%, dan K: 1,36\%.Laju tumbuh tanaman mencerminan kemampuan tanaman dalam menghasilkan bahan kering hasil asimilasi tiap satuan lahan dan tiap satuan waktu yang menandakan kemampuan tanaman tersebut menyerap unsur hara. Laju tumbuh tanaman dipengaruhi oleh kandungan unsur hara yang tersedia bagi tanaman, dalam fase vegetatif unsur hara $\mathrm{N}$ dibutuhkan untuk memacu pertumbuhan tanaman. Hasil penelitian yang telah dilakukan oleh banyak peneliti menunjukkan bahwa bakteri pelarut fosfat dapat menstimulasi pertumbuhan tanaman dengan berbagai mekanisme diantaranya melalui produksi hormon tumbuhan, meningkatkan penyerapan $\mathrm{P}$ pada tumbuhan, fiksasi nitrogen, produksi antibiotik, dan sekresi enzim (Hassani, et al., 2015). Penelitian lain menyebutkan bahwa keberadaan bakteri pelarut fosfat akan meningkatkan ketersediaan dan serapan unsur hara $\mathrm{P}$, sehingga mempengaruhi pertumbuhan tanamna (Rahman et al., 2015). Bakteri pelarut fosfat sering ditemukan berasosiasi di 
dalam tanah, contohnya adalah tanah konvensional dan tanah organik sebab di dalam tanah terdapat akar tanaman yang dapat dimanfaatkan oleh mikroba sebagai nutrisi yaitu berupa eksudat yang dikeluarkan oleh tanaman, sehingga bakteri akan berasosiasi di rhizosfer tanaman(Ilham, 2014).

\section{Serapan Hara P Tanaman}

Interaksi pemberian pupuk organik dan bakteri pelarut pospat mempengaruhi serapan hara $\mathrm{P}$ tanaman. serapan hara $\mathrm{P}$ tanaman akibat interaksi, dapat disajikan pada Tabel 2.

Pengamatan serapan hara Pospat diketahui bahwa pemberian bahan organik Kandang Sapi 10 t/ha dengan bakteri pelarut pospat $0 \mathrm{ml} / \mathrm{l}, 3 \mathrm{ml} / \mathrm{l}, 6 \mathrm{ml} / \mathrm{ldan} 9$ $\mathrm{ml} / \mathrm{l}$ memberikan pengaruh yang nyata dibandingkan dengan pemberian pupuk kandang ayam 10 t/ha dengan bakteri pelarut pospat $0 \mathrm{ml} / \mathrm{ldan} 9 \mathrm{ml} / \mathrm{l}$. Sedangkan perlakuan yang lain tidak memberikan pengaruh yang nyata terhadap serapan $\mathrm{P}$ tanaman kedelai. Pupuk kandang sapi 10 t/ha dengan bakteri pelarut pospat $6 \mathrm{ml} / \mathrm{l}$ meningkatkan serapan P $0,08 \%$ dibandingkan dengan tanpa bakteri pelarut pospat. Hasil penelitian Swain et al.,(2012) menunjukkan bahwa 5 strain bakteri Bacillus yang diisolasi dari bahan organik kotoran sapi mampu melarutkan fosfat anorganik menjadi $\mathrm{PO}_{4}{ }^{3-}$ pada suhu $30^{\circ} \mathrm{C}$ sampai $50^{\circ} \mathrm{C}$. Strain bakteri Bacillus ini diketahui merupakan bakteri Bacillus substilis berdasarkan karakter morfologi, biokimia, dan molekuler.Hal ini berari Bacillus substilis dalam korotan sapi dapat meningkatkan $\mathrm{P}$ tersedia bagi tanaman. Jika jumlah $\mathrm{P}$ terbatas, maka efek paling mencolok adalah terjadinya penurunan luas daun dan jumlah daun. Kekurangan fosfor lebih menghambat pertumbuhan tajuk daripada akar sehingga menyebabkan penurunan ratio bobot kering tajuk dan akar. Menurut Wahyuningsih et al, (2016) ketersediaan $\mathrm{P}$ dalam tanah mempengaruhi serapan $\mathrm{P}$ oleh tanaman, Unsur hara $\mathrm{P}$ yang diserap tanaman mampu merangsang pembentukan akar sehingga pertumbuhan tanaman menjadi baik. Aplikasi bakteri pelarut fosfat dan rock phosphate dapat mempengaruhi karakter fisiologi tanaman, terutama dalam meningkatkan $\mathrm{P}$ Jaringan tanaman fase vegetatif (Lestari et al., 2019).

\section{Jumlah Polong per Tanaman Kedelai}

Interaksi pemberian pupuk organik dan bakteri pelarut pospat (BPF) mampu meningkatkan jumlah polong per tanaman kedelai. Jumlah polong akibat interaksi, dapat disajikan pada (Tabel 3).

Pengamatan jumlah polong tanaman kedelai diketahui bahwa pemberian pupuk organik kandang sapi 10 t/ha dengan bakteri pelarut pospat $6 \mathrm{ml} / \mathrm{lmemberikan}$ pengaruh yang nyata dibandingkan dengan perlakuan yang lainya, tetapi tidak 
berpengaruh nyata dengan perlakuan pospat $\quad 9 \quad \mathrm{ml}$ /literair. kandang sapi 10 t/ha dan bakteri pelarut

Tabel 2. Interaksi pemberian pupuk organik dan bakteri pelarut phosfat terhadap serapan hara $\mathrm{P}(\mathrm{g})$

\begin{tabular}{lcccc}
\hline \multicolumn{1}{c}{ Perlakuan } & \multicolumn{5}{c}{ Pupuk organik } \\
\hline Bakteri Pelarut Pospat & $\begin{array}{c}\text { Kandang Ayam } \\
10 \mathrm{t} / \mathrm{ha}\end{array}$ & $\begin{array}{c}\text { Kandang Sapi } \\
10 \mathrm{t} / \mathrm{ha}\end{array}$ & $\begin{array}{c}\text { Paitan } \\
10 \mathrm{t} / \mathrm{ha}\end{array}$ \\
\hline 0ml/liter air & $1,03 \mathrm{a}$ & $1,76 \mathrm{~b}$ & $1,59 \mathrm{ab}$ \\
$3 \mathrm{ml} /$ liter air & 1,34 ab & $1,63 \mathrm{~b}$ & $1,08 \mathrm{ab}$ \\
$6 \mathrm{ml} /$ liter air & $1,21 \mathrm{ab}$ & $1,91 \mathrm{~b}$ & $1,20 \mathrm{ab}$ \\
$9 \mathrm{ml} /$ liter air & $1,01 \mathrm{a}$ & $1,73 \mathrm{~b}$ & $1,08 \mathrm{ab}$ \\
\hline BNT 5\% & \multicolumn{7}{c}{0,60} \\
\hline KK\% & 24,4 \\
\hline
\end{tabular}

Keterangan: bilangan yang didampingi huruf yang sama tidak berbeda nyata berdasarkan pada BNT $5 \%$.

Tabel 3. Interaksi pemberian pupuk organik dan bakteri pelarut phosfat terhadap jumlah polong per tanaman

\begin{tabular}{lccc}
\hline \multicolumn{5}{c}{ Perlakuan } & Pupuk organik \\
\hline Bakteri Pelarut Pospat & $\begin{array}{r}\text { Kandang Ayam } \\
10 \mathrm{t} / \mathrm{ha}\end{array}$ & $\begin{array}{r}\text { Kandang Sapi } \\
10 \mathrm{t} / \mathrm{ha}\end{array}$ & $\begin{array}{c}\text { Paitan } \\
10 \mathrm{t} / \mathrm{ha}\end{array}$ \\
\hline 0ml/liter air & $12,10 \mathrm{a}$ & $22,70 \mathrm{~b}$ & $18,00 \mathrm{ab}$ \\
$3 \mathrm{ml} /$ liter air & $17,00 \mathrm{ab}$ & $17,10 \mathrm{ab}$ & $14,90 \mathrm{ab}$ \\
$6 \mathrm{ml} /$ liter air & $11,90 \mathrm{a}$ & $29,70 \mathrm{c}$ & $20,60 \mathrm{~b}$ \\
$9 \mathrm{ml} /$ liter air & $15,30 \mathrm{ab}$ & $23,30 \mathrm{bc}$ & $19,40 \mathrm{~b}$ \\
\hline BNT 5\% & 6,70 \\
\hline KK\% & 21,50 \\
\hline Keterangan: bilangan yang didampingi huruf yang sama tidak berbeda nyata berdasarkan pada
\end{tabular}
BNT 5\%.

Pemberian pupuk hijau paitan 10 t/ha juga memberikan pengaruh yang nyata dibandingkan dengan perlakuan pupuk kandang ayam 10 t/ha dengan bakteri pelarut pospat $0 \mathrm{ml} / \mathrm{liter}$ airdan $6 \mathrm{ml} / \mathrm{liter}$ air.Pemberian pupuk organik kandang sapi $10 \mathrm{t} / \mathrm{ha}$ dengan bakteri pelarut pospat 6 ml/ldapat menyediakan unsur hara bagi tanaman sehingga meningkatkan jumlah polong sebesar $0,30 \%$ dibandingkan dengan tanpa bakteri pelarut pospat. Menurut Nurlisan et al. (2014) semakin tinggi persentase polong bernas cenderung meningkatkan bobot biji per tanaman.Fosfor adalah salah satu unsur hara makro yang sangat penting bagi pertumbuhan tanaman. Namun, unsur hara esensial seperti $\mathrm{P}$ berada di dalam tanah dalam keadaan tidak larut. Fosfor terdapat di dalam tanah baik dalam bentuk organik maupun anorganik. Mikroorganisme menyebabkan sejumlah transformasi $\mathrm{P}$ seperti meningkatkan kelarutan senyawa anorganik, memineralisasi senyawa 
organik menjadi fosfat anorganik, mengubah menjadi anion fosfat tersedia untuk sel tanaman, mengoksidasi serta mereduksi senyawa P organik. Salah satu cara untuk mengubah $\mathrm{P}$ tidak terlarut menjadi $\mathrm{P}$ terlarut adalah dengan mikroorganisme yang memiliki aktifitas asam dan basa fosfatase. Strain bakteri Alcaligenes, Burkholderia, Enterobacter, Pseudomonas, Bacillus, Aspergillus, fusarium, Penicillium dan Rhizopus adalah bakteri-bakteri dari tanah dan rhizosfir yang paling efektif dalam melarutkan unsur hara $\mathrm{P}$ (Swain et al., 2012). Menurut Suliasih dan Rahmat (2010), beberapa bakteri tanah seperti bakteri pelarut fosfat mempunyai kemampuan untuk melarutkan $\mathrm{P}$ organik menjadi bentuk fosfat terlarut yang tersedia bagi tanaman.

\section{Indeks Panen}

Interaksi pemberian pupuk organik dan bakteri pelarut pospat (BPF) mempengaruhi indeks panen tanaman kedelai. Indeks panen akibat interaksi, dapat disajikan pada (Tabel 4).

Pengamatan Indeks Panen tanaman kedelai diketahui bahwa pemberian pupuk organik Kandang Sapi 10 t/ha dengan bakteri pelarut pospat $6 \mathrm{ml} / \mathrm{lmemberikan}$ pengaruh yang nyata dibandingkan dengan perlakuan yang lainya. Pemberian pupuk kandang ayam 10 t/ha dengan bakteri pelarut pospat $3 \mathrm{ml} / \mathrm{l}, 6 \mathrm{ml} / \mathrm{ldan} 9 \mathrm{ml} / \mathrm{ljuga}$ memberikan pengaruh yang nyata dibandingkan dengan tanpa bakteri pelarut pospat. Pupuk hijau Paitan 10 t/ha dengan bakteri pelarut pospat $3 \mathrm{ml} / \mathrm{l}, 6 \mathrm{ml} / \mathrm{ldan} 9$ $\mathrm{ml} / \mathrm{l}$, kandang sapi $10 \mathrm{t} / \mathrm{ha}$ dengan bakteri pelarut pospat $3 \mathrm{ml} / \mathrm{ldan}$ kandang ayam 10 t/ha dengan bakteri pelarut pospat 9 $\mathrm{ml} /$ lmemberikan pengaruh yang sama. Pupuk organik kandang sapi 10 t/ha dengan bakteri pelarut pospat 6 $\mathrm{ml} /$ lmenghasilkan indeks panen sebesar 0,42 . Indeks panen menunjukan distribusi bahan kering dalam tanaman yang menunjukkan perimbangan bobot bahan kering yang bernilai ekonomis dengan total bobot bahan kering tanaman pada saat panen. Menurut Hakim (2017) yang mengatakan bahwa indeks panen yang berkisar antara $0,30-0,59$ dapat memberikan hasil biji yang tinggi. Penelitian lain Mohite(2013), menunjukkan bahwa kemampuan bakteri Bacillus substilis dalam meningkatkan produksi hormon IAA dan giberelin pada tanaman mampu meningkatkan penyebaran dan perpanjangan akar pada ubi jalar. Bacillus, pseudomonas etc., juga diketahui dapat mengingkatkan pertumbuhan tanaman buncis, cluster bean, gandum, chick pea serta dapat pula digunakan sebagai biokontrol dan pelarutan P. Fosfor merupakan unsur hara makro yang sangat diperlukan dalam senyawa pada sel dan organel sel tanaman. Senyawa tersebut antara lain membentuk gula fosfat, asam 
nukleat, nukelotida, koenzim dan fotosintesis, asimilasi dan respirasi fosfolipid. Sehingga fosfor memiliki (Liferdi, 2010).

berbagai peranan penting dalam

Tabel 4. Interaksi pemberian pupuk organik dan bakteri pelarut phosfat terhadap indeks panen

\begin{tabular}{lccc}
\hline \multicolumn{1}{c}{ Perlakuan } & \multicolumn{4}{c}{ Pupuk organik } \\
\hline Bakteri Pelarut Pospat & $\begin{array}{c}\text { Kandang Ayam } \\
10 \mathrm{t} / \mathrm{ha}\end{array}$ & $\begin{array}{c}\text { Kandang Sapi } \\
10 \mathrm{t} / \mathrm{ha}\end{array}$ & $\begin{array}{c}\text { Paitan } \\
10 \mathrm{t} / \mathrm{ha}\end{array}$ \\
\hline 0ml/liter air & $0,17 \mathrm{a}$ & $0,19 \mathrm{a}$ & $0,16 \mathrm{a}$ \\
$3 \mathrm{ml} /$ liter air & $0,26 \mathrm{~b}$ & $0,34 \mathrm{c}$ & $0,33 \mathrm{c}$ \\
$6 \mathrm{ml} /$ liter air & $0,30 \mathrm{bc}$ & $0,42 \mathrm{~d}$ & $0,36 \mathrm{c}$ \\
$9 \mathrm{ml}$ liter air & $0,32 \mathrm{c}$ & $0,31 \mathrm{bc}$ & $0,32 \mathrm{c}$ \\
\hline BNT 5\% & & 0,05 & \\
\hline KK\% & & 10,50
\end{tabular}

Keterangan: Bilangan yang didampingi huruf yang sama tidak berbeda nyata berdasarkan pada BNT 5\%.

Tabel 5. Interaksi pemberian pupuk organik dan bakteri pelarut phosfat terhadap bobot biji ( $\mathrm{t} /$ ha)

\begin{tabular}{lcccc}
\hline \multicolumn{1}{c}{ Perlakuan } & \multicolumn{5}{c}{ Pupuk organik } \\
\hline Bakteri Pelarut Pospat & $\begin{array}{c}\text { Kandang Ayam } \\
10 \mathrm{t} / \mathrm{ha}\end{array}$ & $\begin{array}{c}\text { Kandang Sapi } \\
10 \mathrm{t} / \mathrm{ha}\end{array}$ & $\begin{array}{c}\text { Paitan } \\
10 \mathrm{t} / \mathrm{ha}\end{array}$ \\
\hline 0ml/liter air & $1,80 \mathrm{a}$ & $2,00 \mathrm{a}$ & $1,90 \mathrm{a}$ \\
$3 \mathrm{ml} /$ liter air & $1,90 \mathrm{a}$ & $2,60 \mathrm{bc}$ & $2,40 \mathrm{~b}$ \\
$6 \mathrm{ml} /$ liter air & $2,40 \mathrm{~b}$ & $2,70 \mathrm{c}$ & $2,50 \mathrm{bc}$ \\
$9 \mathrm{ml}$ liter air & $2,40 \mathrm{~b}$ & $2,50 \mathrm{bc}$ & $2,40 \mathrm{~b}$ \\
\hline BNT 5\% & & 0,30 & \\
\hline KK\% & 7,80 & \\
\hline
\end{tabular}

Keterangan: Bilangan yang didampingi huruf yang sama tidak berbeda nyata berdasarkan pada uji BNT 5\%.

\section{Bobot Biji Tanaman Kedelai}

Interaksi pemberian pupuk organik dan bakteri pelarut pospat (BPF) mempengaruhi bobot biji tanaman kedelai. Bobot biji akibat interaksi, dapat disajikan pada (Tabel 5).Pengamatan bobot biji diketahui bahwa pemberian pupuk organik pupuk kandang sapi 10 t/ha dengan bakteri pelarut pospat $3 \mathrm{ml} / \mathrm{l}, 6 \mathrm{ml} / \mathrm{l}$ dan 9 $\mathrm{m} /$ lmemberikan pengaruh yang nyata dibandingkan dengan tanpa bakteri pelarut pospat. Perlakuan pupuk kandang ayam 10 t/ha dengan bakteri pelarut pospat6 $\mathrm{ml} / \mathrm{l}$ dan $9 \mathrm{ml} / \mathrm{l}$, pupuk hijau paitan $10 \mathrm{t} / \mathrm{ha}$ dengan bakteri pelarut pospat $3 \mathrm{ml} / \mathrm{l}, 6$ ml/ldan $9 \mathrm{ml} / \mathrm{l}$ memberikan pengaruh yang sama terhadap parameter bobot biji. Unsur hara yang terkandung di pupuk organik berhasil dirubah menjadi tersedia bagi tanaman dengan bantuan bakteri pelarut pospatsehingga bisa diserap tanaman. Hasil yang sama juga ditunjukkan oleh penelitian 
Aviolita et al. (2013) yang menunjukkan bahwa pemberian Bacillus subtilis dapat /Penggunaan bakteri pelarut fosfat sebagai inokulan sekaligus meningkatkan serapan P oleh tanaman, genus Pseudomonas dan Bacillus salah satu pelarut fosfat yang paling kuat. Mekanisme utama untuk pelarutan fosfat mineral adalah produksi asam organik, dan fosfatase peran utama dalam mineralisasi fosfor organik dalam tanah (Purwaningsih et al., 2018). Penelitian Pan et al. (2012) menunjukkan bahwa aktifitas Bacillus subtilis dan Pseudomonas pada bahan organik dapat mempercepat proses dekomposisi dan menyebabkan penurunan $\mathrm{C} / \mathrm{N}$ rasio hingga 25-30, reduksi ion $\mathrm{NH}_{4}{ }^{+}$dan $\mathrm{NO}_{3}^{-}, \mathrm{pH}$ bahan organik menjadi $\pm 7,2$, serta meningkatkan $\mathrm{PO}_{4}{ }^{-3}$. Hal ini menjadi dasar bahwa ada interaksi antara bahan organik dan B. substilis. Selain kemampuan $B$. substiis dalam menguraikan bahan organik dan melarutkan $\mathrm{P}$, B. substilis merupakan mikroorganisme yang terdapat di dalam pencernaan ruminansia. Keberadaan $B$. substilis sangat penting karena bakteri ini mampu menghasilkan enzim selulase yang menguraikan senyawa selulosa pada dinding sel tanaman yang dikonsumsi ruminansia. Isolasi $B$. substilis dari kotoran segar sapi telah banyak dilakukan antara lain oleh Bai et al. (2012) dan Swain et al., (2012). Dekomposisi selulosa oleh mikroorganisme merupakan salah satu tahapan dalam proses dekomposisi bahan organik sehingga dapat diserap oleh tanaman. Bakteri B.subtilis yang mampu memproduksi enzim selulase dimungkinkan berinteraksi dengan paitan yang banyak mengandung selulosa pada dinding selnya. Sehingga poses dekomposisi bahan organik lebih cepat apabila berasosiasi dengan $B$. substilis.

\section{KESIMPULAN}

Interaksi pemberian pupuk organik dan inokulasi BPF mampu meningkatkan laju tumbuh, serapan hara $\mathrm{p}$ tanaman kedelai, jumlah polong per tanaman kedelai, indeks panen dan bobot biji. Pemberian pupuk kandang sapi 10 t/ha $\begin{array}{lllll}\text { dengan inokulasi } & \mathrm{BPF} & 6 & \mathrm{ml} / \mathrm{l}\end{array}$ menghasilkan bobot biji sebesar 2,7 t/ha. Pupuk kandang ayam 10 t/ha dengan inokulasi BPF 6 ml/1 menghasilkan bobot biji sebesar 2,4 t/ha. Pemberian pupuk paitan 10 t/ha dengan inokulasi BPF $6 \mathrm{ml} / 1$ menghasilkan bobot biji sebesar 2,5 t/ha. Pupuk kandang sapi 10 t/ha dengan inokulasi BPF 6 ml/l meningkatkan bobot biji tanaman kedelai sebesar0,5\% dibandingkan dengan tanpa inokulasi BPF dengan pupuk kandang ayam 10 t/ha. Dari hasil penelitian ini direkomendasikan menggunakan perlakuan pupuk kandang sapi 10 t/ha dengan inokulasi BPF 6 ml/l.

\section{DAFTAR PUSTAKA}


Aviolita, A. P. P., M. Martosudiro dan T. Hadiastono. 2013. Pengaruh Plant Growth Promoting Rhizobacteria (PGPR) terhadap infeksi Soybean Mosaic Virus (SMV) pertumbuhan dan produksi pada tanaman kedelai (Glycine max L.) varietas wilis. Jurnal HPT, 1(3): 1-10.

Bai,S.,M. R. Kumar.,D. J. M. Kumar.,P. Balashanmugan., M. D. Balakumaran and P.T. Kalaichelvan.2012. Cellulase production by Bacillusisolated from cow dung. Archives of Applied Science, 4(1): 269-279.

Dulur, N. W. 2010. Kajian bahan organik dan bakteri pelarut fosfat. Agroteksos, 20(9): 119-124.

Hakim, L. 2017. Komponen hasil dan karakter penentu hasil kedelai pada lahan sawah tadah hujan. Jurnal Penelitian Pertanian Tanaman Pangan, 1 (1): 65-71.

Hassani, F., A.Ahmad., M.Ardakani., A.Hamidi and F. Paknejad. 2015. Effectiveness of phosphate solubility bacteria inoculation for improving phosphorus absorption and root growth indies. Biological, 7(1): 199205.

Ilham, I. B. (2014). Isolasi dan identifikasi bakteri pelarut fosfat potensial pada tanah konvensional dan tanah organik. J. Simbiosis, 2 (1): 173183.

Lestari, S. M., R. Soedradjad., S. Soeparjonodan T. C. Setiawati.2019. Aplikasi bakteri pelarut fosfat dan rock phosphate terhadap karakteristik fisiologi tanaman tomat (Solanum lycopersicum L.). J. Bioindustri, 2(1): 319-333.

Liferdi, L. 2010. Efek pemberian fosfat terhadap pertumbuhan dan status hara pada bibit manggis.J. Hort, 2(1): $18-26$.
Mohite, B. 2013. Isolation and characterization of indole acetic acid (IAA) producing bacteria from rhizospheric soil and effect on plant growth. Journal of Soil Sciences and Plant Nutrition, 13 (3): 638-649.

Nurlisan., A. Rasyad dan S. Yoseva. 2014. Pengaruh pemberian pupuk organik terhadap pertumbuhan dan hasil tanaman kedelai (Glycine max (L.) Merril). J. Online Mahasiswa, 1(1):1-9

Pan, L., B.Dam and S.K.Sen. 2012. Composting of common organic waster using microbial inoculans. Biotech, 2: 127-134.

Purwaningsih, N. A ., D. N. Nyana., G. R. M. Temaja dan G. Suastika. 2018. Bakteri pelarut fosfat memicu ketahanan tanaman kedelai (Glycine max) terhadap penyakit soybean mosaic virus. J. Agric. Sci. and Biotechnol, 7( 1): 23-34.

Rahman, R., M. Anshar, dan Bahrudin. 2015. Aplikasi bakteri pelarut fosfat, bakteri penambat nitrogen dan mikoriza terhadap pertumbuhan tanaman cabai (Capsicum annum L.). Agrotekbis, 3(3): 316-328.

Rismawan, F. S., A. S.Karyawati dan T. Islami. 2018. Pengaruh jenis bahan organik pada pertumbuhan dan hasil tanaman kedelai (Glycine max (L.) Merrill). J. Produksi Tanaman, 6 (7): 1543-1548.

Safrianto, R., Syafruddin dan R. Sriwati. 2015. Pertumbuhan dan hasil cabai merah (Capsicum annuum L.) Pada andisol dengan pemberian berbagai sumber pupuk organik dan jenis endomikoriza. J. Floratek, 10 (2) : 34 $-43$

Setyawan, F. 2017. Pengaruh bacillus subtilis dan bahan organik terhadap pertumbuhan dan produksi tanaman kedelai (Glycine max L.). J. Hijau Cendekia, 2 (1) : 21-28. 
Setyawan, F dan F.Setyawan. 2019. Pengaruh SP-36 dan asam humat terhadap pertumbuhan dan produksi tanaman kedelai ( Glycine max L). $J$. Buana Sains, 19 (2): 1-6

Suliasih dan Rahmat. 2010. Aktivitas fosfatase dan pelarutan kalsium fosfat oleh beberapa bakteri pelarut fosfat. Biodiversitas, 8 (1): 23-26.

Swain, M.R., K. Laxminarayana and R.C. Ray. 2012. Phosphorus solubilization by thermotolerant Bacillus subtilis isolated from cow dung microflora. National Academy of Agricultural
Sciences.Agricultural Research, 1: 273-279.

Wahyuningsih., E. Proklamaningsih, dan M. Dwiati. 2016. Serapan fosfor dan pertumbuhan kedelai (Glycinemax) pada tanah ultisol dengan pemberian asam humat.J. Fakultas Biologi, 1 (1): 68-69.

Widawati, S. dan Suliasih, 2006.Populasi bakteri pelarut fosfat (BPF) di Cikaniki, Gunung botol, dan Ciptarasa, serta kemampuannya melarutkan $\mathrm{P}$ terikat di media pikovskaya padat.Biodiversitas, 7 (2): 109-113. 